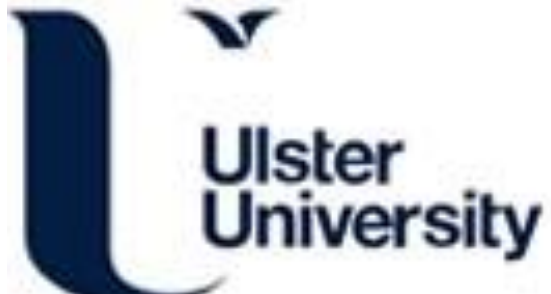

\section{An assessment of the mesoscale to microscale influences on wind turbine energy performance at a peri-urban coastal location from the Irish wind atlas and onsite LiDAR measurements}

Byrne, R., Hewitt, N., Griffiths, P., \& MacArtain, P. (2019). An assessment of the mesoscale to microscale influences on wind turbine energy performance at a peri-urban coastal location from the Irish wind atlas and onsite LiDAR measurements. Sustainable Energy Technologies and Assessments, 36, [100537]. https://doi.org/10.1016/j.seta.2019.100537

Link to publication record in Ulster University Research Portal

Published in:

Sustainable Energy Technologies and Assessments

Publication Status:

Published (in print/issue): 01/12/2019

DOI:

10.1016/j.seta.2019.100537

\section{Document Version}

Author Accepted version

\section{General rights}

Copyright for the publications made accessible via Ulster University's Research Portal is retained by the author(s) and / or other copyright owners and it is a condition of accessing these publications that users recognise and abide by the legal requirements associated with these rights.

\section{Take down policy}

The Research Portal is Ulster University's institutional repository that provides access to Ulster's research outputs. Every effort has been made to ensure that content in the Research Portal does not infringe any person's rights, or applicable UK laws. If you discover content in the Research Portal that you believe breaches copyright or violates any law, please contact pure-support@ulster.ac.uk. 
1 An assessment of the mesoscale to microscale influences on wind turbine

\section{energy performance at a peri-urban coastal location from the Irish wind} atlas and onsite LiDAR measurements

Word count excluding abstract, keywords, abbreviations, acknowledgements and list of references $=6233$

b School of Architecture \& the Built Environment, University of Ulster, Belfast, Northern Ireland

* Corresponding Author

\section{ABSTRACT}

As the global wind energy industry advances to larger wind turbine systems, there still remains opportunities for deploying single medium-to-large-scale wind turbines in distributed wind energy applications. These include community wind farms and "behind-the-meter" wind applications. Such sites tend to be closer to population centres at lower elevations that have more complex wind regimes due to surrounding orography, local terrain and obstacles such as buildings. This research case study examines the regional mesoscale influences and local microscale influences on the post construction measured energy performance of an $850 \mathrm{~kW}$ rated wind turbine, with a $60 \mathrm{~m}$ hub height, at a peri-urban coastal location. The remodelled Irish wind atlas is used to characterise mesoscale and microscale influences on wind resource around the wind turbine site. A directional analysis of modelled predicted annual energy is compared to the measured wind turbine electrical energy rose. Data from a nine month LiDAR measurement campaign is used to assess directional wind shear profiles at the site. The shear profiles are examined with respect to local buildings obstacles to gain insights into the microscale sources of discrepancies between the predicted energy from the wind atlas and actual energy output of the wind turbine.

Keywords

Distributed wind, wind resource, wind atlas, electrical energy rose, LiDAR

Abbreviations

AEP

a.g.l.

a.s.l.

CFD

DkIT

DM

EER

ECMWF

ERA

JMA

LiDAR

LOS

NASA

NECEP

NWP
Annual Energy Production

Above ground level

Above sea level

Computational Fluid Dynamics

Dundalk Institute of Technology

Dual Mode

Electrical Energy Rose

European Centre for Medium-Range Forecasts

ECMWF Re-Analysis

Japanese Meteorological Agency

Light Detection and Ranging

Line of sight

National Aeronautics and Space Administration (USA)

National Centre for Environmental Prediction (USA)

Numerical Weather Prediction 


$\begin{array}{lll}48 & \text { SCADA } & \text { Supervisory Control and Data Acquisition } \\ 49 & \text { SEAI } & \text { Sustainable Energy Authority of Ireland } \\ 50 & \text { MetUM } & \text { Met Office Unified atmospheric Model (UK) } \\ 51 & \text { WAsP } & \text { Wind Atlas Applications Program } \\ 52 & \text { WED } & \text { Wind Energy Density } \\ 53 & \text { WRF } & \text { Weather Research and Forecasting Model } \\ 54 & \text { WPD } & \text { Wind Power Density } \\ 55 & \text { WT } & \text { Wind turbine } \\ 56 & & \end{array}$

\section{Introduction}

Wind energy worldwide continues to grow year on year with a reported global installed capacity of almost $591 \mathrm{GW}$ at the end of 2018 (Dyrholm, 2019). Wind turbine sizes have increased dramatically in the past decade with $10 \mathrm{MW}$ rated wind turbines now coming to the market (Whitmarsh, 2018; Wiser and Bolinger, 2018). This has been advanced by reducing costs in large wind turbine technology and is leading to an increasing move towards offshore wind (Higgins and Foley, 2014; IRENA, 2019). Despite these trends, there are now new opportunities emerging in further onshore distributed wind deployment. These include community owned wind turbines, small wind farms and behind-the-meter onsite generation at large energy user sites (Forsyth et al., 2017; Gorroño et al, 2015; Lantz et al., 2016; Oteri et al., 2018) This is supported in Europe by EU directives and Governments in countries like Ireland that are designing policies for communities and citizens to become energy engaged as prosumers (DCENR, 2015). However, these emerging distributed wind markets still face a number of challenges in their development. One challenge is that suitable wind turbine sizes, typically up to about $1 \mathrm{MW}$ in rated capacity, are not widely manufactured today, as newly available wind turbines have become larger. Another challenge is that onshore distributed wind sites will likely be at lower elevations near populated areas where the wind resource is reduced and has more complex wind flow characteristics. Regional topographic features at the mesoscale, such as hills, land/sea influences, and local microscale obstacles, such as trees and buildings, can impact on the energy and economic performance of a given project and need careful consideration at the outset (Kalmikov et al., 2010; Zhang, 2015). Accurate wind resource assessment can involve expensive measurement campaigns and computer modelling that bring increased upfront project costs. These costs may financially constrain or inhibit some types of distributed wind projects such as behind-the-meter deployments and small community owned wind farms. On the other hand, the impact of less accurate wind energy prediction may lead to projects not meeting their energy output and expected returns on investment, particularly at more complex sites.

A variety of low cost wind resource assessment tools have been developed for distributed wind energy applications. Early approaches, that are still used today, involve extrapolating data from nearby reference masts using linear microscale models such as Wind Atlas Application Program (WAsP) to estimate the annual energy production (AEP) at the site of interest (Landberg et al., 2003; Petersen and Troen, 2012). WAsP is based on models for orographic height variations, terrain roughness and sheltering obstacles that were used in the development of the first European Wind Atlas (Troen and Lundtang Petersen, 1989). A practical limitation is that nearby reference masts with data of sufficient quantity and quality may not always be available. An alternative approach is the use of Numerical weather prediction (NWP) models that can estimate the wind resource over large regions. NWP models are increasingly being refined for wind resource assessment in the wind industry to give high resolution wind climatology and wind data at the regional mesoscale level (Kalverla et al., 2018; Mann et al., 2017). This has been made possible with the availability of satellite weather observation data over recent years and decades. In hind cast mode, these data are reanalysed to generate gridded reanalysis global data sets of a variety of meteorological parameters, including, wind speed and direction at multiple heights in the atmosphere. Reanalysis data sets are provided by organisation such as ECMWF, NASA, NCEP 
and JMA for a range of time and spatial resolutions, in some cases down to 1 hour time resolution and $50 \mathrm{~km}$ spatial resolution (Kim et al., 2018). Mesoscale modelling tools, such as WRF, HARMONIE and UM, use reanalysis data as input to NWP models that downscale meteorological parameters from the global reanalysis data sets to horizontal resolutions of a few km covering areas of a few hundred $\mathrm{km}^{2}$ (Olsen et al., 2017). The downscaling process uses physical models of the atmosphere with sets of equations that model the atmospheric process and its interactions with regional features such as land masses and oceans (Badger et al., 2014). Further downscaling of the data to microscale resolutions in the order of $\sim 100 \mathrm{~m}$ can then be carried out using statistical approaches with tools such as WAsP or with CFD simulations nested in the mesoscale model (Gasset et al., 2012; Rodrigo et al., 2018; Talbot et al., 2012).

In 2013, an open source Irish onshore and offshore wind atlas was remodelled by the UK Met Office, under contract to the Sustainable Energy Authority of Ireland (SEAI), specifically for wind energy development. It gives hourly wind data at 8 end user heights, namely; $20 \mathrm{~m}, 30 \mathrm{~m}, 40 \mathrm{~m}$, $50 \mathrm{~m}, 75 \mathrm{~m}, 100 \mathrm{~m}, 125 \mathrm{~m}$ and $150 \mathrm{~m}$; at any location within the Irish onshore and offshore space. The wind atlas is based on the UK met office unified atmospheric model (MetUM) (Davies et al., 2005; Standen et al., 2017). The MetUM model can be used for NWP modelling from global scale to mesoscale. Bilinear interpolation methods are used to further downscale from the mesoscale to the microscale level. In the development of the Irish wind atlas the ERA-Interim global reanalysis data set from the ECMWF was used to initialise the global model with a $60 \mathrm{~km}$ horizontal resolution and 50 vertical levels. This then provided the initial and spatial boundary conditions for a $12 \mathrm{~km}$ model of Western Europe with 38 vertical levels. This in turn drove three $4 \mathrm{~km}$ domains with 70 vertical levels, one of which was centred over Ireland and UK, to give hourly wind speed components with $4 \mathrm{~km}$ resolution at each level. Six of the 70 levels were below $150 \mathrm{~m}$ at heights of $2.5 \mathrm{~m}, 13.33 \mathrm{~m}, 33.33 \mathrm{~m}, 60 \mathrm{~m}, 93.33 \mathrm{~m}$ and $133.33 \mathrm{~m}$. The $4 \mathrm{~km}$ wind components of the 70 model levels were downscaled onto a $1 \mathrm{~km}$ microscale grid using horizontal bilinear interpolation. Logarithmic wind shear profiles and neutral atmospheric conditions were then assumed to calculate the specified 8 end user heights from the six original downscaled levels below $150 \mathrm{~m}$. The earth's surface properties were deduced from the Corine land database from which surface roughness values were derived (Silva et al., 2007). For each of the 8 end user heights, Weibull scale and shape factors and a representative year of time series hourly wind speed and direction can be extracted for any given location. Open source wind tools such as this can be very useful for distributed and behind-the-meter wind projects in reducing resource assessment costs. However, there remain ongoing challenges in wind resource assessment for wind energy projects at all scales in understanding how mesoscale effects between $10 \mathrm{~s}$ and 100 $\mathrm{s}$ of $\mathrm{km}^{2}$ couple to the microscale down to $100 \mathrm{~m}^{2}$ to improve the accuracy of wind resource assessments. Some of these challenges include validation and verification of models with observations, uncertainty analysis and building a common wind resource assessment framework within the wind industry (Sanz Rodrigo et al., 2017).

This research case study compares the AEP using the Irish wind atlas to the measured postconstruction energy performance of an $850 \mathrm{~kW}$ rated wind turbine, with a $60 \mathrm{~m}$ hub height and $52 \mathrm{~m}$ rotor diameter, in a peri-urban costal location in Ireland. (Byrne et al., 2018) showed that the measured wind turbine electrical energy rose (EER) at the site, based on 5 years of 10-minute time series wind turbine SCADA data, had distinct directional characteristics. In this study, the energy impact of mesoscale and microscale features around wind turbine site are examined in the context of how they each contribute to the shape measured wind turbine EER. As the spatial downscaling resolution of the Irish wind atlas is $1 \mathrm{~km}$, mesoscale influences are assessed at 150 $\mathrm{m}$ above ground level (a.g.l.) in 16 directional sectors, where local obstacles are assumed to have little influence. At the $60 \mathrm{~m}$ wind turbine hub height, the directional differences between the predicted and measured energy are compared to examine the site specific microscale obstacle impacts on the turbine's energy performance. In addition, onsite directional wind shear profiles from Light Detection and Ranging (LiDAR) measurements are investigated to give further insights into the directional differences between the energy predictions using the wind atlas and the 
measured EER. The study demonstrates some of the limitations of the Irish wind atlas in capturing the influence of local obstacles that may be of use to prospective distributed wind project developments in peri-urban locations in Ireland.

\section{Site Description}

\subsection{Site location}

The wind turbine at Dundalk Institute of Technology (DkIT) is located in a peri-urban area, $13 \mathrm{~m}$ above sea level (a.s.l.), on the east coast of Ireland as shown in Fig. 1. The turbine is a Vestas V52 rated at $850 \mathrm{~kW}$ with a hub height of $60 \mathrm{~m}$ and a rotor diameter of $52 \mathrm{~m}$. In Ireland the general prevailing winds are from the south west (Dwyer, 2012). However, proximity of the site to the Irish Sea to the east means that coastal influences may have an impact.

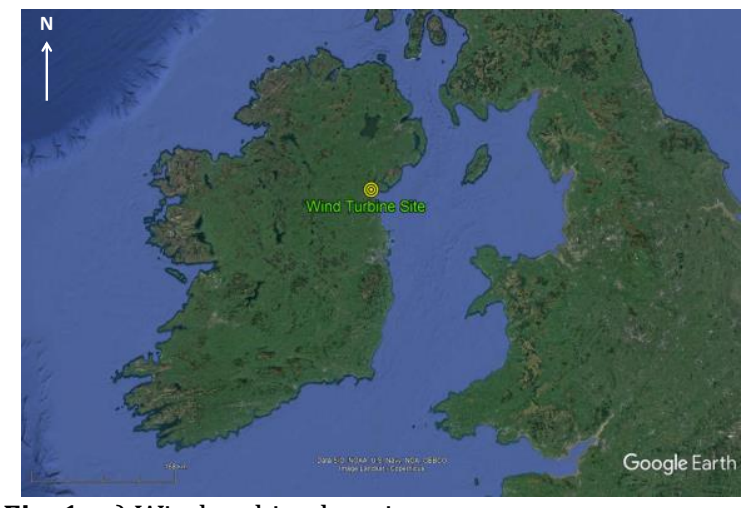

Fig. 1. a) Wind turbine location

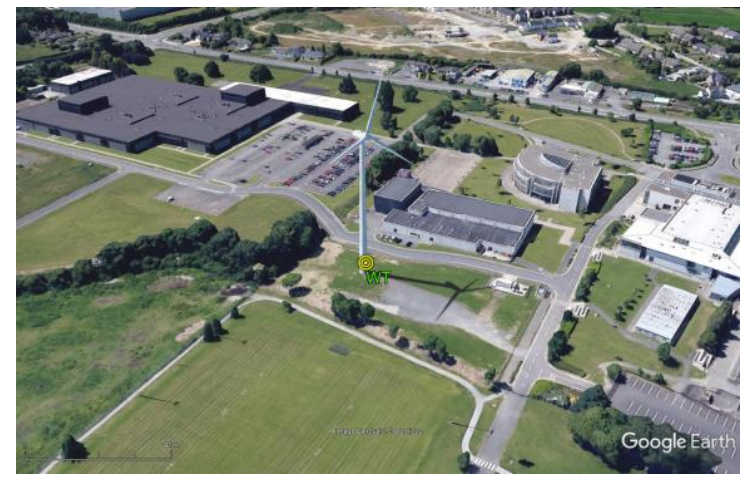

b) Wind turbine on the DkIT campus

The upper part of Fig. 2 shows more details of the regional and local features surrounding the wind turbine site "WT". Dundalk town lies to the north. At the regional scale there are hills "A" approximately $7 \mathrm{~km}$ to northeast with relatively open terrain from the west to the south. Dundalk bay to the east of the site opens out to the Irish Sea. In addition to the wind turbine site, the points M1, OS1 and OS2 mark locations, both on and offshore, where one-year wind atlas hourly data is used to assess the coastal and regional orographic influences on wind resource at $150 \mathrm{~m}$ a.g.l. The coordinates and distances of these points from the wind turbine location are given in Table 1.

There are a variety of local obstacle features comprising of buildings of various types and densities surrounding the wind turbine site. The lower part of Fig. 2 shows the local area where the principal building obstacles are outlined. The physical and spatial details of the obstacles are given in Table 2. The points M2, M3 and M4 mark locations in the local area where wind atlas data are used to asses the influence of local obstacles on the wind resource at $60 \mathrm{~m}$ as well as at the 60 $\mathrm{m}$ hub height of the wind turbine location itself. 

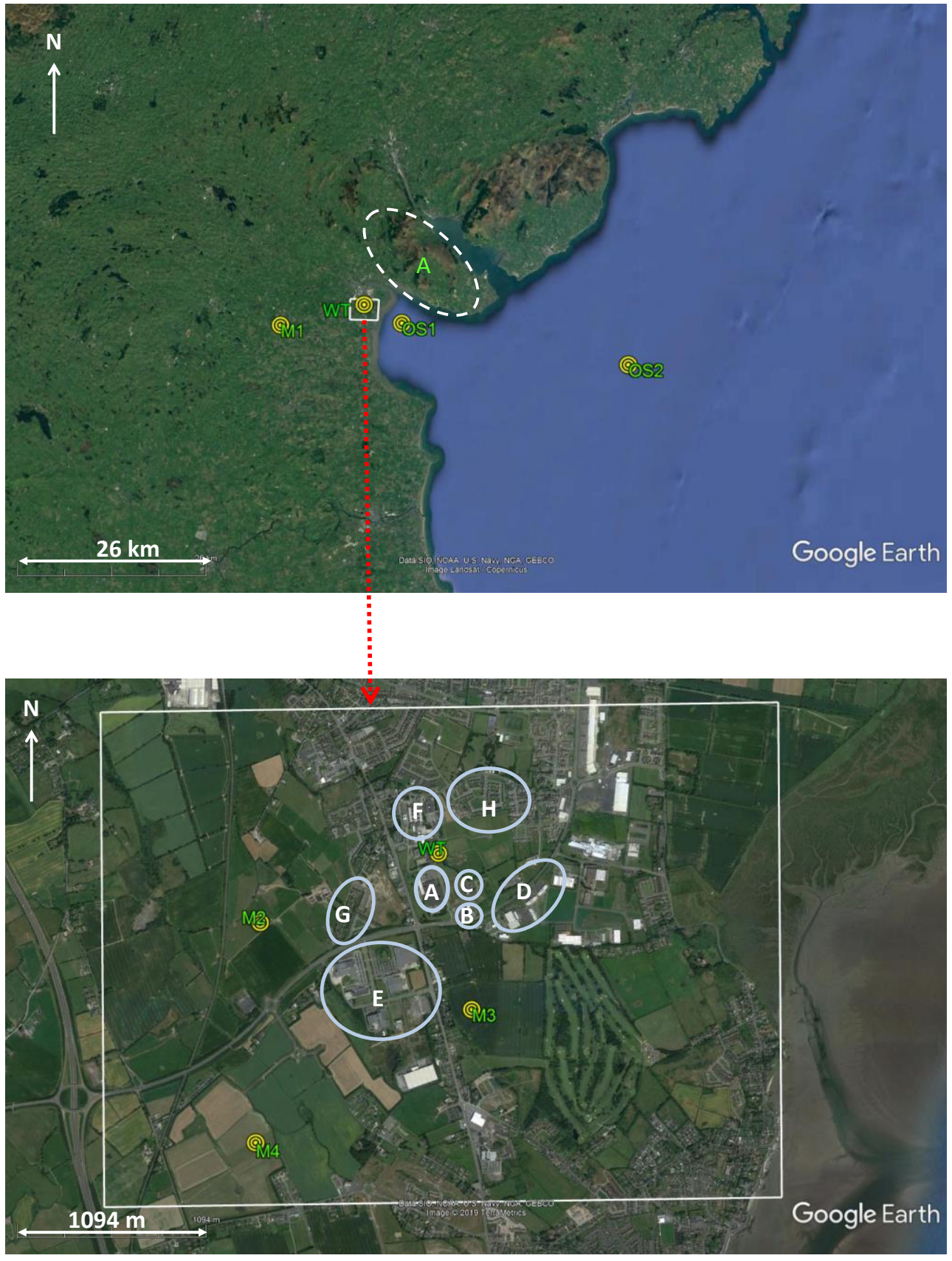

201
Fig. 2. Site features around the wind turbine "WT" location: regional (upper) and local (lower)

\begin{tabular}{llll}
\hline \multicolumn{2}{l}{ Table 1 } \\
Site locations for wind atlas mesoscale and microscale analysis \\
\hline \\
Site & Coordinates & $\begin{array}{l}\text { Elevation a.s.l. } \\
(\mathrm{m})\end{array}$ & $\begin{array}{l}\text { LOS distance to } \\
\text { WT (km) }\end{array}$ \\
\hline $\mathrm{WT}$ & $53.983542^{\circ} \mathrm{N}, 6.391389^{\circ} \mathrm{W}$ & $13 \mathrm{~m}$ & - \\
OS1 & $53.961977^{\circ} \mathrm{N}, 6.308429^{\circ} \mathrm{W}$ & $0 \mathrm{~m}$ & $5.8 \mathrm{~km}$ \\
OS2 & $53.920155^{\circ} \mathrm{N}, 5.819431^{\circ} \mathrm{W}$ & $0 \mathrm{~m}$ & $38 \mathrm{~km}$ \\
$\mathrm{M} 1$ & $53.953000^{\circ} \mathrm{N}, 6.569000^{\circ} \mathrm{W}$ & $60 \mathrm{~m}$ & $12.2 \mathrm{~km}$ \\
M2 & $53.979837^{\circ} \mathrm{N}, 6.407429^{\circ} \mathrm{W}$ & $12 \mathrm{~m}$ & $1130 \mathrm{~m}$ \\
$\mathrm{M} 3$ & $53.975234^{\circ} \mathrm{N}, 6.388389^{\circ} \mathrm{W}$ & $20 \mathrm{~m}$ & $950 \mathrm{~m}$ \\
$\mathrm{M} 4$ & $53.968265^{\circ} \mathrm{N}, 6.407595^{\circ} \mathrm{W}$ & $23 \mathrm{~m}$ & $2000 \mathrm{~m}$ \\
\hline
\end{tabular}




\begin{tabular}{|c|c|c|c|c|}
\hline \multicolumn{5}{|c|}{$\begin{array}{l}\text { Table } 2 \\
\text { Local building obstacles }\end{array}$} \\
\hline Obstacles & Description & $\begin{array}{l}\text { Distance from } \\
\text { turbine }(\mathrm{m})\end{array}$ & $\begin{array}{l}\text { Height a.g.l. } \\
\text { (m) }\end{array}$ & $\begin{array}{l}\text { Cross sectional } \\
\text { width as viewed } \\
\text { from wind turbine } \\
(\mathrm{m})\end{array}$ \\
\hline $\bar{A}$ & $\begin{array}{l}\text { Industrial } \\
\text { building }\end{array}$ & $151-315$ & 7 & 150 \\
\hline B & Tall hotel & $335-420$ & 47 & 70 \\
\hline $\mathrm{C}$ & $\begin{array}{l}\text { Student } \\
\text { apartments }\end{array}$ & $241-312$ & 13 & 90 \\
\hline $\mathrm{D}$ & Office blocks & $520-670$ & $8-13$ & 420 \\
\hline E & $\begin{array}{l}\text { Cluster of } \\
\text { industrial } \\
\text { buildings }\end{array}$ & $550-1100$ & 12 & 635 \\
\hline $\mathrm{F}$ & $\begin{array}{l}\text { Campus } \\
\text { building }\end{array}$ & $80-330$ & 11 & 240 \\
\hline G & Row of houses & $487-728$ & 7 & 320 \\
\hline $\mathrm{H}$ & Houses & $225-650$ & 7 & 600 \\
\hline
\end{tabular}

\section{Methods}

Firstly, the mesoscale influences from regional orographic and the land-sea interface area are assessed from the Irish wind atlas data, at selected locations, in the region around the wind turbine site. Secondly, a directional breakdown of the wind turbine AEP predicted from the wind atlas, as would be done at the prefeasibility stage of a project, is compared to the actual postconstruction EER of the wind turbine. Thirdly, insights into the differences between the predicted and measured directional energy are given with the aid of onsite directional wind shear measurements up to 300 m using a Doppler LiDAR.

\subsection{Mesoscale assessment method}

Mesoscale influences from regional orographic and the land-sea interface area are assessed from the Irish wind atlas data at the selected locations WT, M1, OS1 and OS2 outlined in Fig. 2. An hourly time series of wind speed and direction data, over a representative year, at the maximum available height of $150 \mathrm{~m}$ from the wind atlas is analysed. Annual wind roses and directional wind energy density (WED) plots in 16 directional sectors are produced for each location. The directional WED is estimated from the mean wind power density (WPD) derived as follows:

Given that:

$229 P=\operatorname{power}(W)$

$230 \rho=$ density of air $\left(\mathrm{kg} / \mathrm{m}^{3}\right)$

$231 A=$ intercepted area normal to wind flow $\left(\mathrm{m}^{2}\right)$

$232 U=$ wind speed $(\mathrm{m} / \mathrm{s})$

$233 j=$ directional sector number 
$J=$ total number of directional sectors (16 in this study)

$n_{j}=$ is the $n^{\text {th }}$ wind data point in directional sector $j$

$N_{j}=$ total number of wind data points in direction $j$

$N_{\text {tot }}=$ total number of wind data points in all directions

Then:

Power available in the wind

$P(U, \rho, A)=\frac{1}{2} \rho A U^{3}$

Wind power density per unit area is:

$W P D(U, \rho)=\frac{1}{2} \rho U^{3}$

The mean power density in a given direction $j$ is:

$W P D_{j}=\frac{1}{2 N_{j}} \sum_{n_{j}=1}^{n_{j}=N_{j}} \rho_{n_{j}} U_{n_{j}}{ }^{3}$

The wind energy density (WED) in a given direction is the mean power density multiplied by the proportion of total time the wind comes from that direction as:

$W E D_{j}=W P D_{j} \frac{N_{j}}{N_{t o t}}$

The total wind energy density is given by:

$W E D_{t o t}=\sum_{j=1}^{j=J} W E D_{j}$

Wind roses and WED plots predicted by the wind atlas, at all four local sites, are compared to assess the predicted variation of the wind resource across the region.

\subsection{Microscale assessment method}

At the wind turbine hub height of $60 \mathrm{~m}$, the location WT and three other local locations, M2, M3 and M4, around the wind turbine site, are analysed to assess influences of local building obstacles. An hourly time series of wind speed and direction data, over a representative year, are generated from the wind atlas at heights of $50 \mathrm{~m}$ and $75 \mathrm{~m}$. These are scaled to $60 \mathrm{~m}$ wind turbine hub height based on the log law (6), assuming neutral atmospheric stability, as was used in the wind atlas itself to generate the 8 end user heights below $150 \mathrm{~m}$, described in the introduction section.

$U(z)=\frac{U^{*}}{k} \ln \left(\frac{z-d}{z_{o}}\right)$

Where: $d$ = displacement height of the wind flow $(\mathrm{m})$

$z=$ height above the ground $(m)$

$z_{o}=$ surface roughness length $(\mathrm{m})$

$U(z)=$ horizontal wind speed at height $z(\mathrm{~m} / \mathrm{s})$

$U^{*}=$ surface friction velocity $(\mathrm{m} / \mathrm{s})$ 
A displacement height of $3 \mathrm{~m}$ is chosen based on values applicable to semi-urban fabric and industrial areas as used in the Irish wind atlas (Best et al., 2008).

$z_{o}=e^{\left(\frac{\mathrm{U}\left(z_{1}\right) \ln \left(z_{2}\right)-\mathrm{U}\left(z_{2}\right) \ln \left(z_{1}\right)}{\mathrm{U}\left(z_{1}\right)-\mathrm{U}\left(z_{2}\right)}\right)}$

Wind roses and WED plots predicted by the wind atlas at all four local sites at $60 \mathrm{~m}$ a.g.l. are compared to assess the variation of the wind resource across the site. At the WT location, directional wind speed distributions with direction are computed from the wind atlas time series data. The predicted directional AEP of the wind turbine is assessed using the fitted directional Weibull scale and shape parameters and the wind turbine power curve. Time series wind data is characterised by the well-known Weibull distribution described by:

Where

$p(U)=$ probability density function (dimensionless)

$U=$ mean wind speed $(\mathrm{m} / \mathrm{s})$

292

$c=$ scale factor $(\mathrm{m} / \mathrm{s})$

293

$k$ = shape factor (dimensionless)

The scale factor $\mathrm{c}$ and shape $\mathrm{k}$ factor can be determined from fitting a Weibull distribution to the 296 wind speed data distribution using the method of moments (Azad et al., 2014).

The cumulative density function is described as:

$F(U)=1-e^{\left[-\left(\frac{U}{c}\right)^{k}\right]}$

299

For a given Weibull probability density distribution, the corresponding cumulative density function gives the portion or fraction of wind speed values that are below a given value of $U$ or else can be used to determine the proportion of wind speed values between two given wind speeds. It is used in combination with a wind turbine power curve to calculate the AEP (10).

304

$A E P(k W h)=\sum_{i}^{N_{i}}\left\{e^{-\left[\left(\frac{U_{i-1, j}}{c}\right)^{k}\right]}-e^{-\left[\left(\frac{U_{i, j}}{c}\right)^{k}\right]}\right\} P_{w_{i}}\left(\frac{U_{i-1, j}+U_{i, j}}{2}\right) N h$

Where:

308

$i=$ wind speed bin number

309

$U_{i}=$ mean wind speed in wind speed bin $i(\mathrm{~m} / \mathrm{s})$

310 $P w_{i}=$ wind turbine average electrical power in a given wind speed bin from its power curve $(k W)$ 
The directional AEP for a given directional sector bin " $\mathrm{j}$ " is based on the fitted Weibull shape and scale factors of the wind speed distribution for the given direction and the wind turbine power curve. This is implemented by the following equation:

$A E P(j)=\sum_{1}^{N(j)_{i}}\left\{e^{-\left[\left(\frac{U(j)_{i-1}}{c(j)}\right)^{k(j)}\right]}-e^{-\left[\left(\frac{U(j)_{i}}{c(j)}\right)^{k(j)}\right]}\right\} P_{w_{i}}\left(\frac{U(j)_{i-1}+U(j)_{i}}{2}\right) N h(j)$

Where $j=360 \%$ sector angular width

In this study, the angular sector width chosen is $22.5^{\circ}$, giving " $\mathrm{j}$ " a total of 16 directional bins.

The total AEP is the sum of the AEPs in each direction given as:

The measured EER of the wind turbine from SCADA system data is determined from directional distributions of 10-minute averaged measurements of wind speed and wind turbine yaw direction data in combination with the wind turbine power curve. A normalised year of wind data based on SCADA measurements between 2008 and 2015 is used to minimise the effects of interannual variation. The directional breakdown of the wind turbine AEP predicted from the wind atlas is compared to the normalised 1-year EER of the wind turbine.

\subsection{LiDAR data measurement}

To help understand differences between AEP predictions based on the wind atlas and the wind turbine EER, a short-term LiDAR measurement campaign over a 9-month period from March to November 2018 was carried out at the wind turbine site. The LiDAR is a continuous wave scanning ZephIR dual mode (DM) LiDAR. A continuous wave LiDAR transmits and focuses an infra-red laser beam at the desired location and detects the Doppler shifted back scattered beam from the moving aerosols in the wind flow (Clifton et al, 2013; Peña et al., 2013). The LiDAR is ground-mounted in this case. The infra-red laser beam is directed at an angle at $30^{\circ}$ from the vertical in order to resolve the horizontal wind velocity and three dimensional wind velocity components. The transmitted beam is focused at the given height of interest and scans a circle in 50 steps, making a wind measurement at each step, around the circular (conical) scan. Subsequent data post processing in the LiDAR system determines the wind velocity components at the given height (Branlard et al., 2013). For practical reasons, in this case, the LiDAR is positioned approximately $60 \mathrm{~m}$ northwest from the base of the wind turbine. Ten-minute averaged wind speed and direction measurements at 11 heights are taken, namely $10 \mathrm{~m}, 20 \mathrm{~m} 34$ $\mathrm{m}, 38 \mathrm{~m}, 60 \mathrm{~m}, 72 \mathrm{~m}, 86 \mathrm{~m}, 120 \mathrm{~m}, 200 \mathrm{~m}, 250 \mathrm{~m}$ and $300 \mathrm{~m}$. Plots of the average horizontal wind speed against height in 16 directional sectors are produced to give directional vertical wind speed profiles. The vertical wind speed profiles in each directional sector are examined in relation to obstacles in each sector as viewed from the wind turbine. 


\section{Results}

\subsection{Mesoscale Results}

The wind roses at $150 \mathrm{~m}$ a.g.l. for locations OS1, OS2, M2 and the wind turbine site WT are shown in Fig. 3.

\subsubsection{Wind roses}
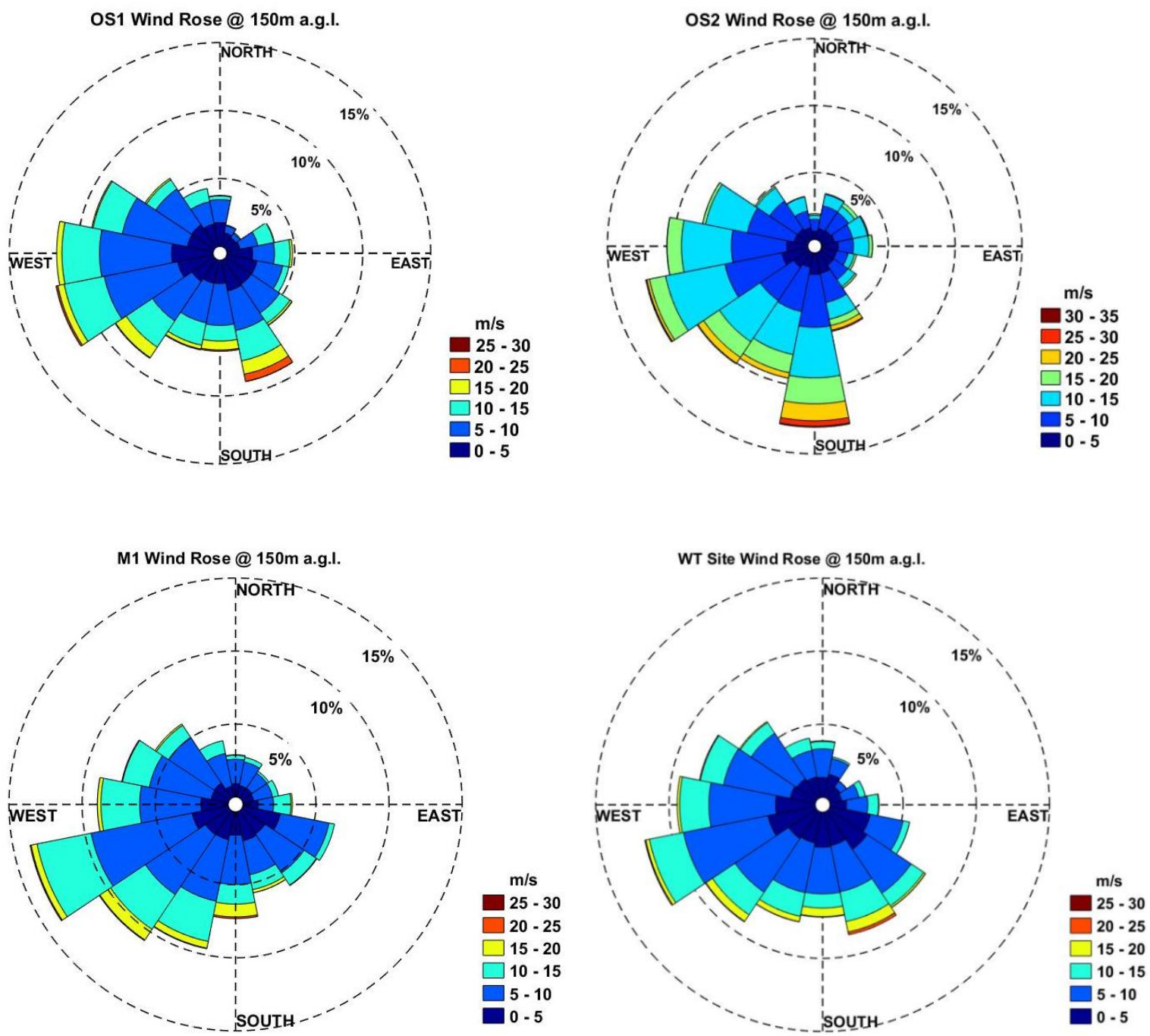

Fig. 3. Wind roses at $150 \mathrm{~m}$ a.g.l. at locations OS1, OS2, M2 and the wind turbine site WT

In all cases, a significant proportion of the winds comes from west and west south west, as expected. Interestingly, the offshore location OS1 that is $38 \mathrm{~km}$ to the east of the site shows very significant winds from the south. The offshore location OS1 in Dundalk Bay, approximately 5.8 $\mathrm{km}$ from the wind turbine site, shows significant south easterly winds. This appears to indicate that southerly offshore winds are being steered through Dundalk Bay by the hills A to the north of the bay. The south easterly winds appear significantly reduced at location M1, approximately $12 \mathrm{~km}$ inland, where the southwest winds dominate, while the Irish Sea has a much reduced influence. This may indicate, at a mesoscale level, that normally south westerly winds from the Atlantic Ocean incident on the south coast of Ireland are being steered northwards up the Irish Sea between Ireland and Britain, thus increasing the wind potential along the east coast of Ireland. 
This is also indicated in another study on the nearshore wind and wave potential for Ireland (Gallagher et al., 2016).

\subsubsection{Wind energy density (WED)}

Overlaid plots of directional WED in Fig. 4 show a direct comparison of the directional changes and reduction in the energy available at the mesoscale level.

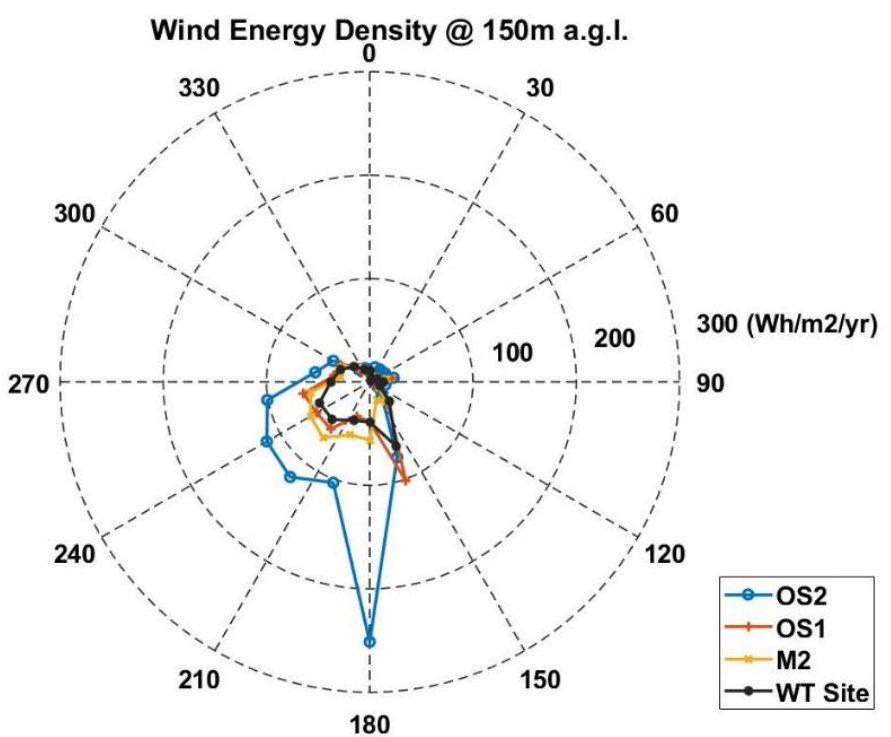

Fig. 4. Wind energy density comparison at $150 \mathrm{~m}$ a.g.l. between the four sites

The significant reduction in the WED and its changing directional distribution can be seen moving from offshore location OS2 to OS1, with further reduction moving on to the wind turbine site WT. This further illustrates the impact that Dundalk Bay and the hills to the north of the bay may be having on the wind resource. In all cases, little energy comes from the northeast sectors, as these are not the prevailing wind directions. In addition, the hills to the northeast may be having a blocking effect on the lighter winds in these sectors. At the inland location M1, the south easterly components are significantly reduced, while the southwest sectors contain the dominant energy sectors. This again highlights the reduced influence of the Irish Sea at this location.

\subsection{Microscale results}

\subsubsection{Wind roses and wind energy density}

The wind roses and directional WED at the wind turbine hub height of $60 \mathrm{~m}$ a.g.l. are shown in Fig. 5 and Fig. 6, respectively, for the microscale comparisons. 

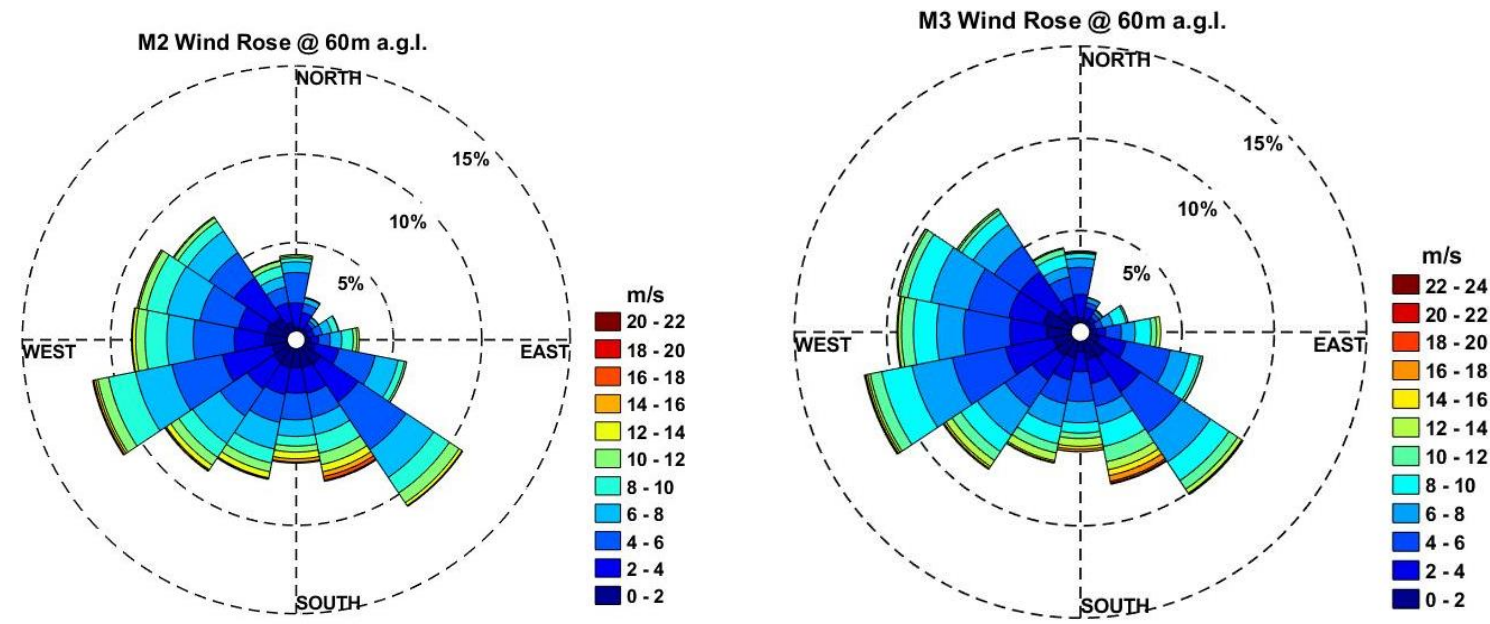

419
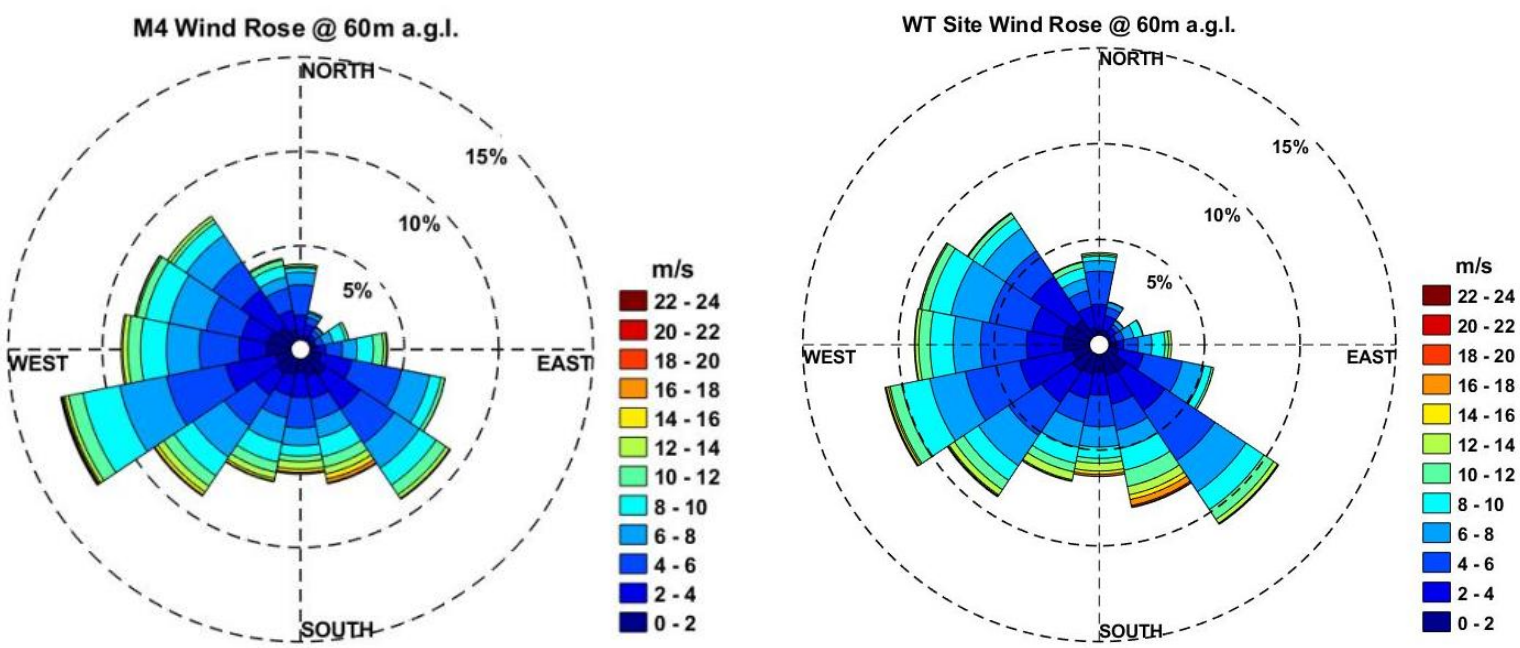

420

421

422

423

424

425

426

Fig. 5. Wind roses at local locations M2, M3, M4 and the wind turbine site WT

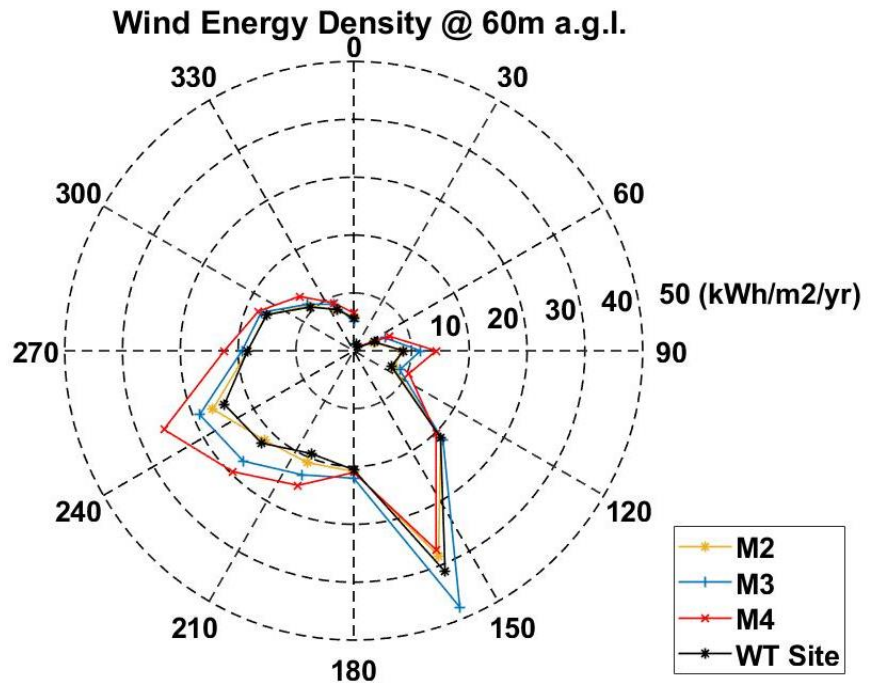

Fig. 6. Wind energy density comparison at local sites M2, M3, M4 and the wind turbine site WT 
Location M4 has the highest energy available in the west southwest sector, but the lowest energy available in the south southeast sector, while location M3 has the highest energy available in the south southeast sector. Comparing all four locations, the wind turbine site itself appears to have the lowest energy available in all directions apart from the south southeast sector where it has the second lowest energy available. This highlights the influences of local obstacles on the wind resource at the microscale, such as the buildings around the turbine site.

\subsubsection{Site directional AEP and EER comparisons}

The predicted wind turbine AEP from the wind atlas is estimated using the Weibull shape and scale parameters of the directional wind speed distributions with the wind turbine power curve as discussed in section 3.2. The predicted and measured directional wind speed distributions are shown in Fig. 7 with the specific Weibull parameter values shown in Table 4. The wind turbine power curve is shown in Fig. 8.
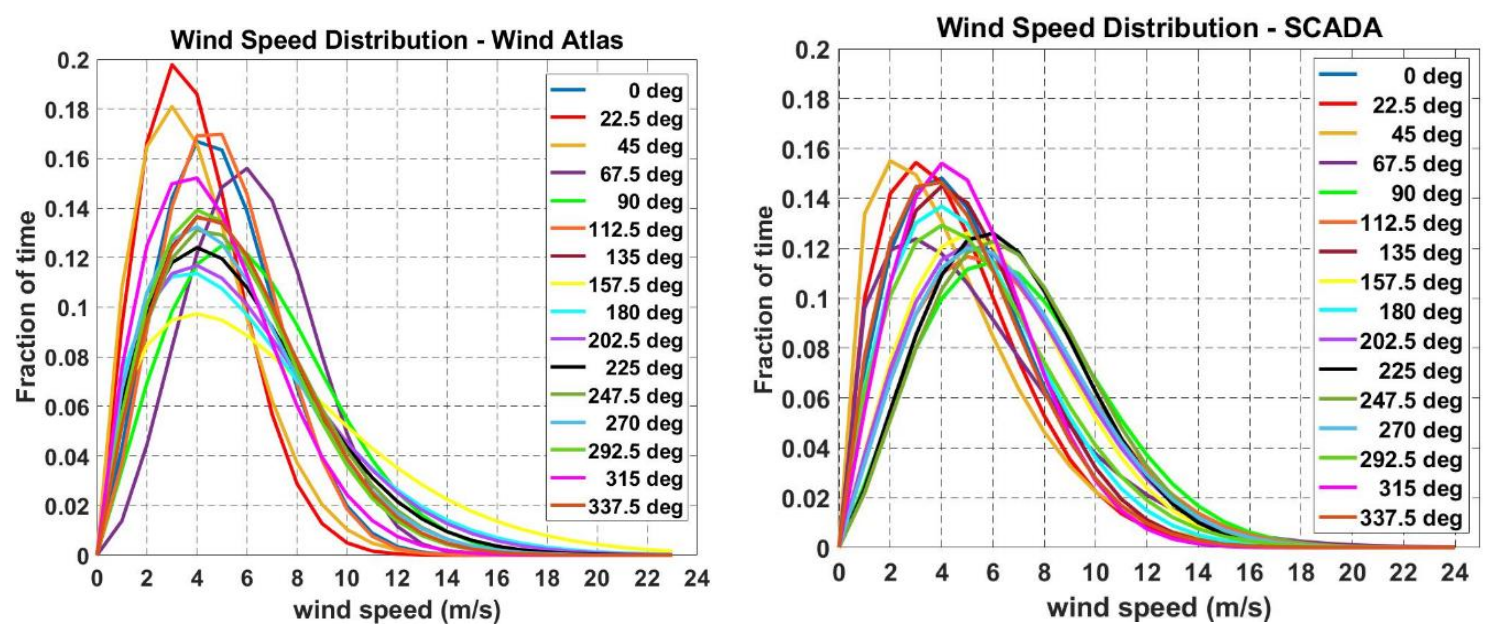

Fig. 7. Directional wind distributions at the turbine site predicted by the wind atlas and measured by the wind turbine SCADA system

Table 3

Directional wind speed distribution parameter values

\begin{tabular}{l|llll|llll}
\hline & \multicolumn{4}{|l|}{ Wind Atlas predicted } & \multicolumn{3}{l}{ Derived from measured wind turbine SCADA data } \\
\hline Sector $\left({ }^{\circ}\right)$ & $\mathrm{c}$ & $\mathrm{k}$ & Hours & Freq. (\%) & $\mathrm{c}$ & $\mathrm{k}$ & Hours & Freq. (\%) \\
\hline 22.5 & 5.60 & 2.29 & 378 & 4.32 & 5.56 & 1.89 & 383.83 & 4.69 \\
45 & 4.40 & 2.06 & 157 & 1.79 & 5.08 & 1.71 & 215.60 & 2.63 \\
67.5 & 4.51 & 1.84 & 92 & 1.05 & 4.77 & 1.47 & 107.53 & 1.31 \\
90 & 6.93 & 2.72 & 162 & 1.85 & 6.01 & 1.49 & 127.10 & 1.55 \\
112.5 & 7.07 & 2.09 & 287 & 3.28 & 7.85 & 2.15 & 325.87 & 3.98 \\
135 & 5.65 & 2.40 & 491 & 5.61 & 7.36 & 2.01 & 612.93 & 7.48 \\
157.5 & 6.18 & 1.96 & 945 & 10.79 & 5.84 & 1.96 & 611.30 & 7.46 \\
180 & 7.72 & 1.55 & 716 & 8.17 & 6.91 & 2.05 & 623.73 & 7.61 \\
202.5 & 6.67 & 1.60 & 559 & 6.38 & 5.98 & 1.86 & 344.63 & 4.21 \\
225 & 6.63 & 1.67 & 594 & 6.78 & 7.12 & 2.03 & 426.77 & 5.21 \\
247.5 & 6.43 & 1.77 & 794 & 9.06 & 7.42 & 2.27 & 730.87 & 8.92 \\
270 & 6.35 & 1.92 & 957 & 10.92 & 7.65 & 2.28 & 1088.27 & 13.28 \\
292.5 & 6.08 & 1.80 & 803 & 9.17 & 7.28 & 2.07 & 880.47 & 10.75 \\
315 & 6.04 & 1.94 & 796 & 9.09 & 6.26 & 1.81 & 648.30 & 7.91 \\
337.5 & 5.38 & 1.89 & 684 & 7.81 & 5.69 & 2.07 & 641.27 & 7.83 \\
360 & 6.21 & 1.98 & 345 & 3.94 & 5.50 & 1.84 & 424.20 & 5.18 \\
\hline
\end{tabular}




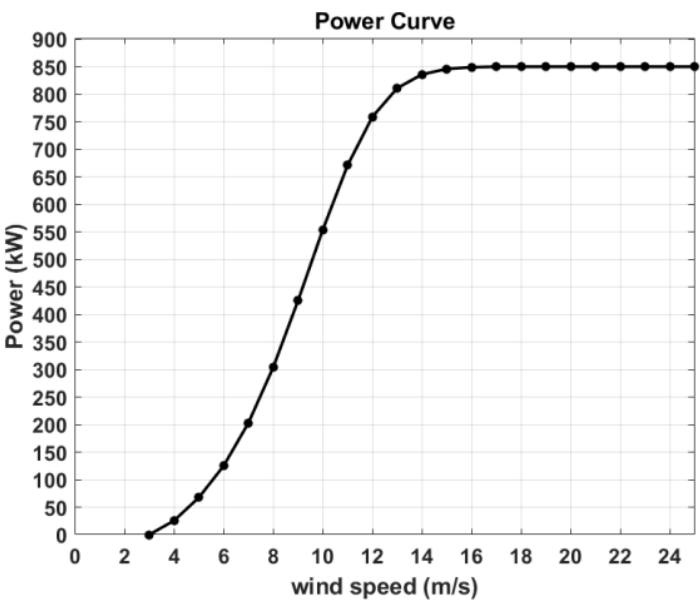

Fig. 8. Wind turbine power curve

Table 4 compares the directional values of the predicted AEP from wind atlas data and measured 460 wind turbine EER, while Fig. 9 shows the overlay comparison on the site plan view.

\begin{tabular}{lllll}
\hline $\begin{array}{l}\text { Table 4 } \\
\text { Predicted and measured energy values }\end{array}$ & & \\
\hline Sector (deg.) & $\begin{array}{l}\text { Predicted AEP } \\
(\mathrm{kWh})\end{array}$ & $\begin{array}{l}\text { Measured } \\
\text { EER } \\
(\mathrm{kWh})\end{array}$ & $\begin{array}{l}\text { Difference (Predicted- } \\
\text { Measured) } \\
(\mathrm{kWh})\end{array}$ & $\begin{array}{l}\% \\
\text { Difference }\end{array}$ \\
\hline 22.5 & 9322 & 20198 & -10876 & -117 \\
45 & 6610 & 10184 & -3573 & -54 \\
67.5 & 31076 & 22043 & 9034 & 29 \\
90 & 61991 & 87057 & -25066 & -40 \\
112.5 & 56093 & 131525 & -75432 & -134 \\
135 & 153248 & 77431 & 75818 & 49 \\
157.5 & 192854 & 118144 & 74711 & 39 \\
180 & 116737 & 47354 & 69382 & 59 \\
202.5 & 120609 & 87705 & 32904 & 27 \\
225 & 148020 & 157395 & -9375 & -6 \\
247.5 & 167082 & 249880 & -82798 & -50 \\
270 & 130878 & 183866 & -52988 & -40 \\
292.5 & 122745 & 99865 & 22880 & 19 \\
315 & 79825 & 70549 & 9276 & 12 \\
337.5 & 56406 & 47790 & 8616 & 15 \\
360 & 43143 & 43104 & 39 & 0 \\
& 1496639 & 1454087 & 42551 & 3 \\
\hline
\end{tabular}

461

Notably, the measured EER shows significantly higher energy values in the west southwest sectors, while lower values are seen in the south and south southeast sectors. Higher values are again seen east in southeast sector. 


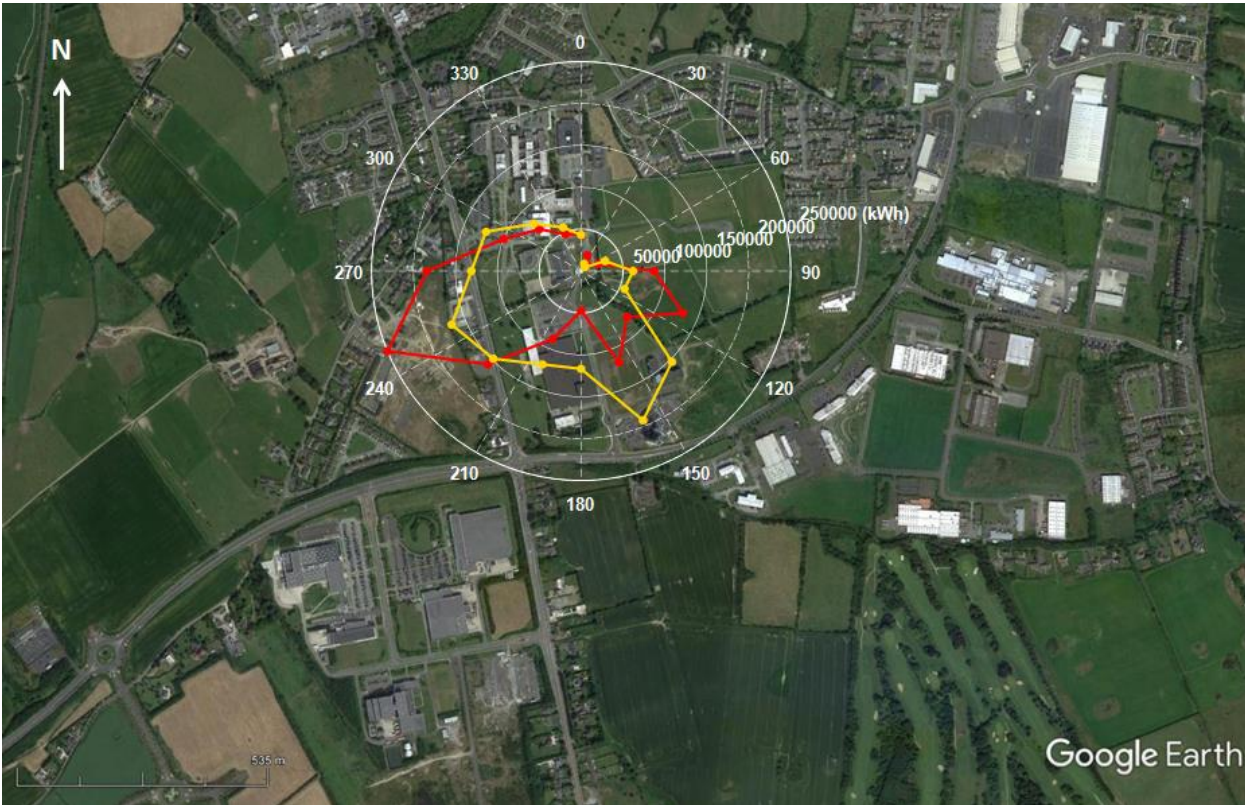

Fig. 9. Overlaid plots of the predicted wind turbine AEP (yellow) and the measured EER (red) on plan view

The total annual electrical energy values in each case are very similar with only a $3 \%$ difference between the total and predicted. However, the difference in the directional distribution indicates that energy is being steered or enhanced in some directions and reduced in other directions.

The directional percentage differences where measured EER exceeds the predicted energy vary from $6 \%$ to $134 \%$ with the highest percentage exceedances in the east southeast $\left(112.5^{\circ}\right)$ and north northeast $\left(22.5^{\circ}\right)$. However, the highest absolute differences in energy exceedance occur in the west south west $\left(247.5^{\circ}\right)$ and east south east $\left(112.5^{\circ}\right)$ sectors. The directional percentage differences where the measured energy is less than the predicted energy vary from $12 \%$ to $59 \%$. The highest absolute differences in energy deficit occur from the south southeast $\left(135^{\circ}\right)$ to south southwest $\left(202.5^{\circ}\right)$ sectors inclusive.

Fig. 10 shows pictures of some of the main local obstacles, outlined in Table 2, as viewed from the turbine at hub height. The directions with largest absolute energy deficits occur in the sectors that contain buildings A, B and E. Interestingly, the neighbouring sector to the west south west $\left(247.5^{\circ}\right)$, with the less dense obstacles $\mathrm{G}$, has the highest absolute energy exceedance. It suggests that in the south west sector the low and broad buildings A and E, that are approximately $20 \%$ of the turbine height and up to $1.1 \mathrm{~km}$ away, are having a significant reducing influence on the energy performance of the wind turbine in the south west sector. However, the energy exceedance in the west southwest sector also suggests that buildings $A$ and $E$ may be steering energy into the west southwest sector.

In the southeast sector, the high energy exceedance difference at (112.5), combined with a high energy deficit in the south east sector, suggests the influence of the tall and narrow building $B$ and lower buildings $\mathrm{D}$ both reducing or steering energy to the east. Interestingly, the measured EER appears to show two energy peaks in directions to either side of buildings B and D. This suggests some wind channelling effects along the road between buildings A and B along with some wind steering to the east of building D. The east and northeast sectors are not in prevailing wind directions and are more difficult to assess due to the regional hill and coastal influences, as was described in the mesoscale results. The northwest sectors show small deficits in energy differences that may be due to the more uniform surface roughness of the town to the north of the site being underestimated by the wind atlas. 


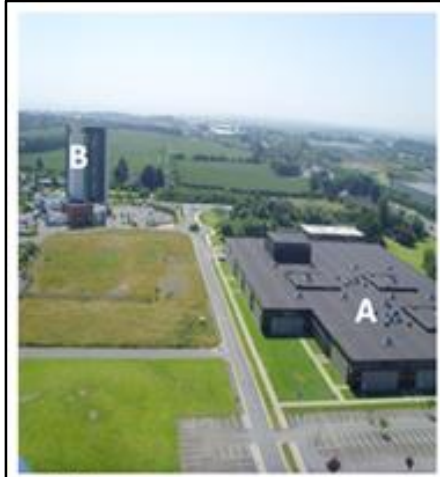

SSE

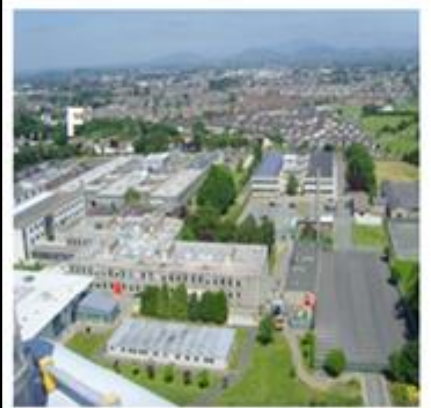

N

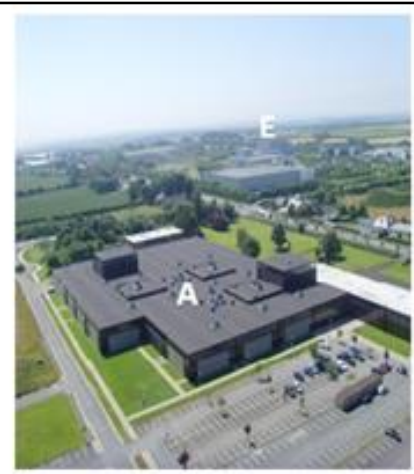

SSW

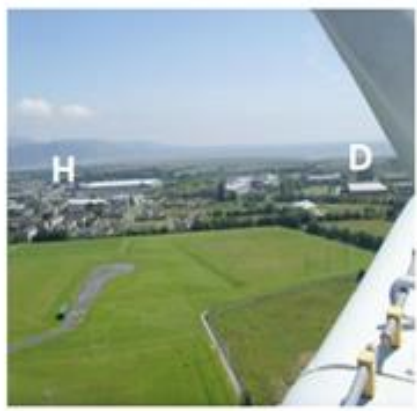

ENE

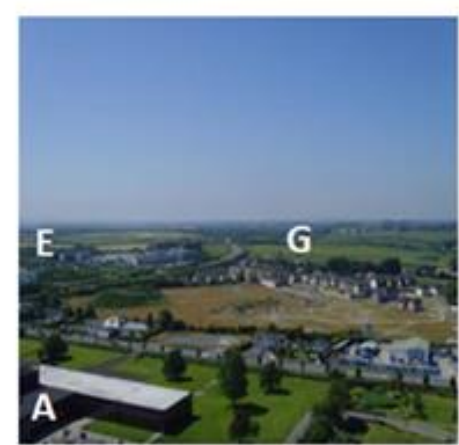

WSW

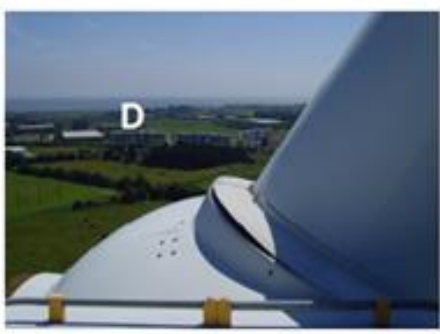

SE

Fig. 10. Views from wind turbine nacelle at hub height showing some of the local obstacles outlined in Table 2

\subsubsection{Predicted AEP comparison of WT site with other local locations}

The AEP estimated from the wind atlas at the other local locations, outlined in Fig. 2, are shown in Table 5. In line with the results shown Fig. 6, the wind turbine location WT appears to be a poorer performing site compared to M3 and M4.

\begin{tabular}{lll}
\hline \multicolumn{3}{l}{ Table 5} \\
AEP comparison & at other local location \\
\hline Location & $\begin{array}{l}\text { Predicted AEP } \\
(\mathrm{kWh})\end{array}$ & $\begin{array}{l}\% \\
\text { Difference }\end{array}$ \\
\hline WT & 1496600 & - \\
M2 & 1477200 & -1 \\
M3 & 1600100 & +7 \\
M4 & 1678800 & +12
\end{tabular}

Location M3, which is to the south of the buildings, performs up to 8\% better than M2 which is to the west of the buildings. This shows that a good wind fetch to the east coast can be significant in the coastal regions despite the general prevailing winds coming from the southwest. In Fig. 6, location M2 has the poorest WED in the southeast sector. This could be explained by the influence of the buildings to the east of M2. Although M4 has the highest AEP, the influence of the coast is less, as it is further inland, but has it has a better fetch to the west due to it being at a slightly more elevated location. However, a turbine located at M4 would not be a practical possibility for the DkIT site. Interestingly, the results suggest that location M3 would be preferred over M2, which highlights the influence of the proximity to Dundalk Bay on the local wind environment. 


\subsection{LiDAR wind shear profiles}

\subsubsection{Directional wind shear profiles}

Directional wind shear profiles from the 11 measurement heights for 16 directions at the wind turbine site WT are shown in Fig. 11.
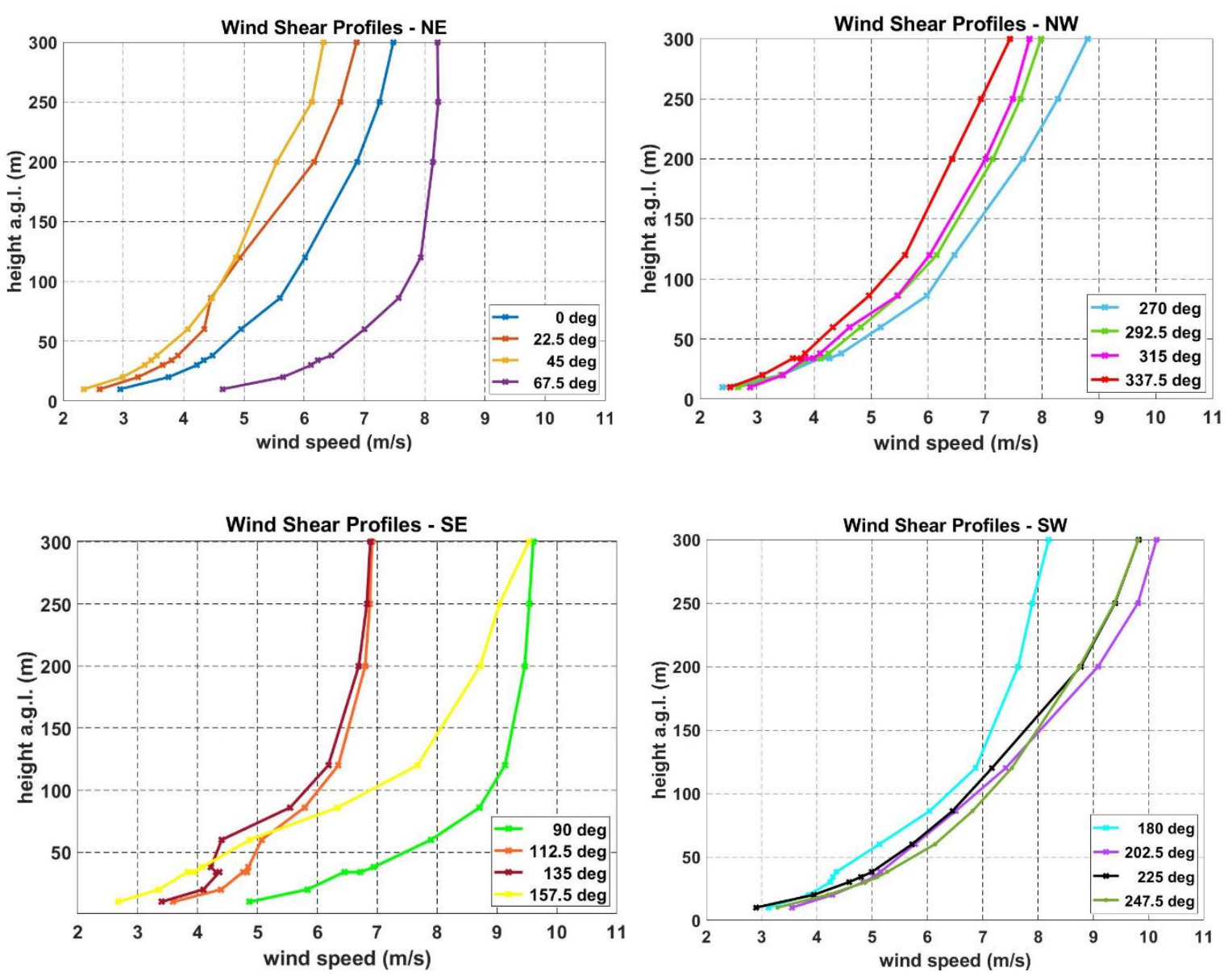

Fig. 11. Directional wind shear profiles from LiDAR measurements at wind turbine site

In the southwest sectors, the wind speeds at $247.5^{\circ}$ are highest at the turbine hub height of $60 \mathrm{~m}$ and up to $150 \mathrm{~m}$. At 202.5 , the hub height wind speed is lower, but the wind shear becomes greater above approximately $140 \mathrm{~m}$. This is in line with the EER and suggests that winds are being steered by buildings $A$ and $E$ towards the $247.5^{\circ}$ sector, between buildings A and F, with reduced winds in the $202.5^{\circ}$ and $225^{\circ}$ sectors. Wind shear profiles in the southeast sectors show reduced shear above $\sim 100 \mathrm{~m}$ a.g.l. at $112.5^{\circ}$ and $135^{\circ}$ indicating the more open fetch to the sea, but become complicated at heights below $100 \mathrm{~m}$. These sectors contain obstacles B, C and D coinciding with reduced energy output in the EER. The profiles at $135^{\circ}$ are in the wind turbine rotor wake, evident from the wind shear profile from $34 \mathrm{~m}$ to $86 \mathrm{~m}$ in this sector. The wind speeds increase again at $157.5^{\circ}$ which indicates possible channelling between building obstacles $A$ and B. This is in line with the energy peak observed the EER in Fig. 9 along the road between buildings $A$ and B. In the northwest sectors, the west sector $\left(270^{\circ}\right)$ is the most dominant. At $315^{\circ}$, the wind shear below $100 \mathrm{~m}$ becomes more complicated. This may be caused by the effects from lower to higher surface roughness due to local buildings and town to the north. This agrees with the small energy deficits observed in the EER. The northeast to east sectors have less dense local obstacles, but have the more complex mesoscale features of the hill to the north and the land sea interface 
with Dundalk Bay. Wind shear profiles centred on $22.5^{\circ}$ and $45^{\circ}$ are lowest, indicating wind blocking by the hills to the northeast. Wind speed and shear increases from the north centred at $0^{\circ}$, which may indicate some channelling of winds between building areas $\mathrm{F}$ and $\mathrm{H}$ matching the small increase in the EER from the north. At 67.5, there is a significant increase in wind speed and wind shear up to $100 \mathrm{~m}$ that may indicate the onset steering of wind from the east by the hills to the north. This is more evident from $90^{\circ}$ where the easterly winds from the 2018 spring storm appear to be steered on to the site.

\section{Discussion}

It has been shown that both the mesoscale and microscale scale factors influence the energy performance of a wind turbine, at a given site, in a distributed wind project development. At the mesoscale level the geographical size and location of Ireland, Irish Sea and the west coast of Britain appears to have steering influences on the prevailing south westerly winds northwards up the Irish Sea i.e. increasing the predicted southerly wind speeds at offshore and onshore locations near to the east coast. The wind atlas assessment shows a significant southerly component in the offshore winds approximately $30 \mathrm{~km}$ offshore east of the wind turbine site. Closer to the shore at Dundalk this southerly wind component appears to back to the southeast creating significant south easterly winds through Dundalk Bay towards the wind turbine site, which enhances wind energy from this direction. These south easterly winds become significantly reduced at approximately $10 \mathrm{~km}$ inland from the coast indicating that distributed wind projects closer to the coast will have enhanced energy potential and project viability. Contrary to this, the hills to the north of Dundalk Bay appear to have an energy reducing impact on any winds from the northeast, although this is not general prevailing wind direction. Encouragingly, a comparison of the AEP for the site from the wind atlas data is within 3\% of the measured wind turbine EER. This indicates how beneficial the open source Irish wind atlas is for prefeasibility studies and the progress that is being made in mesoscale wind atlas development. However, analysis of the EER from the wind turbine SCADA data shows notable directional differences in comparison with the directional breakdown of AEP predicted from the wind atlas data. An overlay of wind turbine EER and the predicted directional AEP on a local plan view highlight directional differences that can be related to the influence of local features such as building obstacles. These influences can reduce and/or redistribute the energy with direction. Buildings can have multiple influences on wind flow at a given location such as wind speed up, channelling, steering and blocking depending on the building sizes and spatial layout (Hassanli et al., 2019; Toparlar et al., 2017). In this study, it is observed that a $12 \mathrm{~m}$ high broad building cluster, at a distance of $550 \mathrm{~m}$ to $1100 \mathrm{~m}$ from the turbine location, has a bigger influence on the turbine energy output compared to a $47 \mathrm{~m}$ high narrow building at a distance of $335 \mathrm{~m}$ to $420 \mathrm{~m}$. The horizontal cross-sectional width, as viewed from the turbine, is $635 \mathrm{~m}$ and $70 \mathrm{~m}$ for the broad building cluster and taller narrow building respectively. This is supported by onsite LiDAR measured directional vertical wind shear profiles. Therefore, obstacles of at least $20 \%$ of the wind turbine hub height and within at least 20 times the turbine hub height can influence the wind turbine energy performance. Energy reductions due to obstacles can be compensated for through wind steering or channelling depending on their physical geometries and spatial layout. The downscaling process from mesoscale to microscale in the Irish wind atlas to a $1 \mathrm{~km}$ resolution does not fully capture these local microscale influences. Therefore, accurate wind turbine micro-siting of medium-to-large-scale wind turbine within periurban areas will be critical to optimise project viability by minimising local energy reduction and taking advantage of local energy gains due to obstacles. For distributed wind energy to become more cost-effective in peri-urban environments that involve single or a small number of wind turbines, further research in cost-effective wind resource and energy prediction tools will be required in order to improve wind turbine micro-siting accuracy. This will require additional measurements, testing and validation of both linear and CFD models for micro-siting medium and large scale wind turbines in urbanised environments. 


\section{Conclusions}

The study compares the annual energy prediction using a mesoscale modelled wind atlas with real wind turbine performance in a peri-urban area and results in agreement with $3 \%$ in this case. Mesoscale influences of regional hills in wind blocking and steering of offshore winds towards the costal wind turbine site appear to be well represented. Proximity, within $10 \mathrm{~km}$, to the east coast also gives an enhanced wind resource. The results also show that at the microscale level more complex directional sensitivities in the directional energy from measurements are not fully captured by the predictions from the wind atlas. These sensitives are dependent on the spatial layout of obstacles around the site and can include numerous effects such as wind speed up, channelling, steering and blocking depending on obstacle features. Buildings with heights as low as $20 \%$ of the turbine hub height within $1 \mathrm{~km}$ of the wind turbine location have an influence. It is seen that wind turbine energy output enhancement in some directions compensates for energy losses in other directions. The directional sector percentage gains in the measured energy compared to predicted energy vary from $6 \%$ to $134 \%$, while the percentage losses vary from $12 \%$ to $59 \%$. The study highlights that accurate wind turbine micro-siting of medium-to-large-scale wind turbine within peri-urban areas will be critical to optimise project viability and the growth of a distributed wind industry in the future.

\section{ACKNOWLEDGEMENTS:}

"The authors wish to acknowledge the support of the INTERREG VA SPIRE2 project. This research was supported by the European Union's INTERREG VA Programme (Grant No. INT-VA/049), managed by the Special EU Programmes Body (SEUPB). The views and opinions expressed in this document do not necessarily reflect those of the European Commission or the Special EU Programmes Body (SEUPB)." 


\section{References}

1 Azad, A. K., Rasul, M. G. and Yusaf, T. (2014) 'Statistical diagnosis of the best weibull methods for wind power assessment for agricultural applications', Energies. doi: 10.3390/en7053056.

2 Badger, J. et al. (2014) 'Wind-Climate Estimation Based on Mesoscale and Microscale Modeling: Statistical-Dynamical Downscaling for Wind Energy Applications', Journal of Applied Meteorology and Climatology, 53(8), pp. 1901-1919. doi: 10.1175/JAMC-D-13-0147.1.

3 Best, M. et al. (2008) Small-scale Wind Energy - Technical Report, Urban Wind Energy Research Project Part 1 - A Review of Existing Knowledge Prepared for the Carbon Trust. Available at: https://www.carbontrust.com/media/85174/small-scale-wind-energy-technical-report.pdf. [accessed 12.12.2018]

4 Branlard, E. et al. (2013) 'Retrieving wind statistics from average spectrum of continuouswave lidar', Atmospheric Measurement Techniques, 6(7), pp. 1673-1683. doi: 10.5194/amt-61673-2013.

5 Byrne, R. et al. (2018) 'Observed site obstacle impacts on the energy performance of a large scale urban wind turbine using an electrical energy rose ', Energy for Sustainable Development , 43, pp. 23-37. doi.org/10.1016/j.esd.2017.12.002.

6 Clifton, A., Elliott, D. and Courtney, M. (2013) Expert Group Study on Recommended Practices 15. Ground-Based Vertically-Profiling Remote Sensing for Wind Resource Assessment. Available at: https://community.ieawind.org/publications/rp. [accessed 28.01.2019]

7 Davies, T. et al. (2005) 'A new dynamical core for the Met Office's global and regional modelling of the atmosphere', Quarterly Journal of the Royal Meteorological Society. John Wiley \& Sons, Ltd, 131(608), pp. 1759-1782. doi: 10.1256/qj.04.101.

8 DCENR (2015) Ireland's Transition to a Low Carbon Energy Future. Dublin. Available at: https://www.dccae.gov.ie/en-ie/energy/publications/Pages/White-Paper-on-EnergyPolicy.aspx. [accessed 15.01.2019]

9 Dwyer, N. (2012) Status of Ireland's Climate. Environmental Protection Agency, Dublin. Avaiable at: http://www.epa.ie/pubs/reports/research/climate/CCRP26\%20\%20Status\%20of\%20Ireland's\%20Climate\%202012.pdf [accessed 13.01.2019]

10 Dyrholm, M. (2019) Global Wind Energy Report. Brussels. Available at: https://gwec.net/wpcontent/uploads/2019/04/GWEC-Global-Wind-Report-2018.pdf [accessed 20.06.2019]

11 Forsyth, T. et al. (2017) The Distributed Wind Cost Taxonomy. Golden CO, USA. NREL/TP5000-67992. Available at: https://www.nrel.gov/docs/fy17osti/67992.pdf [accessed 22.01.2019]

12 Gallagher, S. et al. (2016) 'The nearshore wind and wave energy potential of Ireland: A high resolution assessment of availability and accessibility', Renewable Energy. Pergamon, 88, pp. 494-516. doi: 10.1016/J.RENENE.2015.11.010.

13 Gasset, N., Landry, M. and Gagnon, Y. (2012) 'A Comparison of Wind Flow Models for Wind Resource Assessment in Wind Energy Applications', Energies, 5(11), pp. 4288-4322. doi: $10.3390 /$ en5114288.

14 Gorroño Albizu, L., Maegaard, P. and Kruse, J. (2015) Community Wind Power for the World. 
Denmark. Nordic Folk Centre Denmark. Avaiable at:

http://www.folkecenter.eu/PDF/Social/01.Community-Power-for-the-World.pdf

15 Hassanli, S. et al. (2019) 'Application of through-building openings for wind energy harvesting in built environment', Journal of Wind Engineering and Industrial Aerodynamics. Elsevier, 184, pp. 445-455. doi: 10.1016/J.JWEIA.2018.11.030.

16 Higgins, P. and Foley, A. (2014) 'The evolution of offshore wind power in the United Kingdom', Renewable and Sustainable Energy Reviews, 37, pp. 599-612. doi: https://doi.org/10.1016/j.rser.2014.05.058.

17 IRENA (2019), Renewable Power Generation Costs in 2018, International Renewable Energy Agency, Abu Dhabi . ISBN: 978-92-9260-126-3. Available at:

https://www.irena.org/publications/2019/May/Renewable-power-generation-costs-in-2018 [accessed 21.06.2019]

18 Kalmikov, A. et al. (2010) 'Wind power resource assessment in complex urban environments: MIT campus case-study using CFD Analysis', in AWEA Wind Power Conference.

19 Kalverla, P. et al. (2018) 'Evaluation of three mainstream numerical weather prediction models with observations from meteorological mast IJmuiden at the North Sea', Wind Energy. doi: $10.1002 /$ we.2267.

20 Kim, H.-G., Kim, J.-Y. and Kang, Y.-H. (2018) 'Comparative Evaluation of the Third-Generation Reanalysis Data for Wind Resource Assessment of the Southwestern Offshore in South Korea', Atmosphere, 9(2). doi: 10.3390/atmos9020073.

21 Landberg, L. et al. (2003) 'Wind Resource Estimation-An Overview', Wind Energy. John Wiley \& Sons, Ltd, 6(3), pp. 261-271. doi: 10.1002/we.94.

22 Lantz, E. et al. (2016) Assessing the Future of Distributed Wind: Opportunities for Behind-theMeter Projects. Golden CO, USA. NREL/TP-6A20-67337. Available at: https://www.nrel.gov/docs/fy17osti/67337.pdf [accessed 23.01.2019]

23 Mann, J. et al. (2017) 'Complex terrain experiments in the New EuropeanWind Atlas', Philosophical Transactions of the Royal Society A: Mathematical, Physical and Engineering Sciences. doi: 10.1098/rsta.2016.0101.

24 Olsen, B. T. et al. (2017) 'An intercomparison of mesoscale models at simple sites for wind energy applications', Wind Energ. Sci. Copernicus Publications, 2(1), pp. 211-228. doi: 10.5194/wes-2-211-2017.

25 Oteri, F. et al. (2018) 2017 State of Wind Development in the United States by Region. Golden CO, USA. NREL/TP-5000-70738. doi: 10.2172/1433800

26 Peña, A. et al. (2013) Remote Sensing for Wind Energy, DTU Wind Energy-E-Report-0029(EN). Roskilde. Available at: www.vind energi.dk.

27 Petersen, E. L. and Troen, I. (2012) 'Wind conditions and resource assessment', Wiley Interdisciplinary Reviews: Energy and Environment. doi: 10.1002/wene.4.

28 Rodrigo, J. S. et al. (2018) 'Comparing Meso-Micro Methodologies for Annual Wind Resource Assessment and Turbine Siting at Cabauw', Journal of Physics: Conference Series. IOP Publishing, 1037, p. 72030. doi: 10.1088/1742-6596/1037/7/072030. 
29 Sanz Rodrigo, J. et al. (2017) 'Mesoscale to microscale wind farm flow modeling and evaluation', Wiley Interdisciplinary Reviews: Energy and Environment. John Wiley \& Sons, Ltd, 6(2), p. e214. doi: 10.1002/wene.214.

30 Silva, J. et al. (2007) 'Roughness length classification of Corine Land Cover classes', Proceedings of EWEC 2007.

31 Standen, J. et al. (2017) 'Prediction of local wind climatology from Met Office models: Virtual Met Mast techniques', Wind Energy. John Wiley \& Sons, Ltd, 20(3), pp. 411-430. doi: 10.1002/we.2013.

32 Talbot, C., Bou-Zeid, E. and Smith, J. (2012) 'Nested Mesoscale Large-Eddy Simulations with WRF: Performance in Real Test Cases', Journal of Hydrometeorology, 13(5), pp. 1421-1441. doi: 10.1175/JHM-D-11-048.1.

33 Toparlar, Y. et al. (2017) 'A review on the CFD analysis of urban microclimate', Renewable and Sustainable Energy Reviews. Pergamon, 80, pp. 1613-1640. doi: 10.1016/J.RSER.2017.05.248.

34 Troen, I. and Lundtang Petersen, E. (1989) European Wind Atlas. Roskilde: Risø National Laboratory. Available at: https://orbit.dtu.dk. [accessed 25.01.2019]

35 Whitmarsh, M. (2018) Offshore Wind Industry Prospectus. United Kingdom. Availiable at: https://www.renewableuk.com/resource/resmgr/publications/catapult_prospectus_final.pdf [accessed 24.01.2019]

36 Wiser, R. and Bolinger, M. (2018) 2017 Wind Technologies Market Report. US Department of Energy, Oak Ridge, TN 37831-0062. Available at:

https://emp.lbl.gov/sites/default/files/2017_wind_technologies_market_report.pdf [accessed 21.01. 2019]

37 Zhang, M. H. (2015) Wind Resource Assessment and Micro-siting. 1st edn. Singapore: Wiley. ISBN:9781118900109, doi: 10.1002/9781118900116. 